
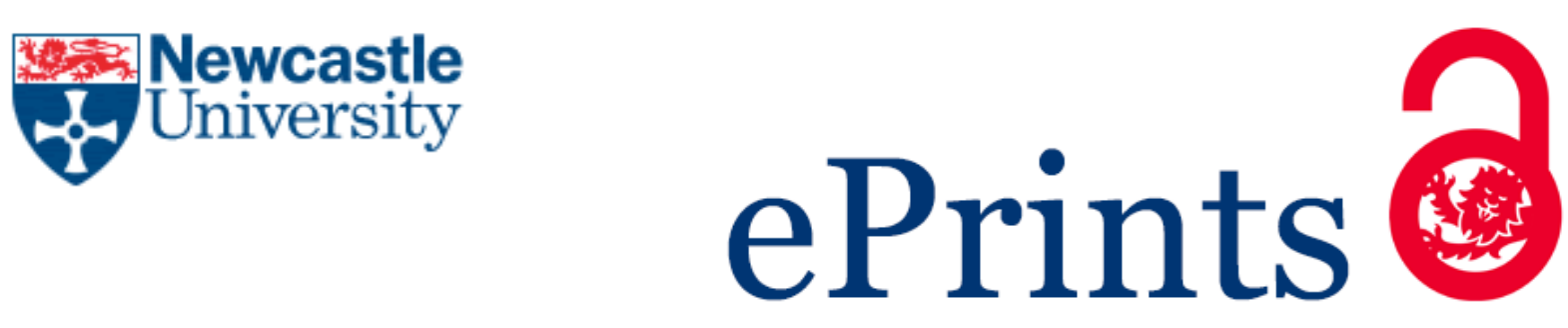

Ryan S. Disclosure and HIV Transmission. Journal of Criminal Law 2015, 79(6), 395-410.

\title{
Copyright:
}

CC S. Ryan 2015.

DOI link to article:

http://dx.doi.org/10.1177/0022018315614444

Date deposited:

$17 / 12 / 2015$

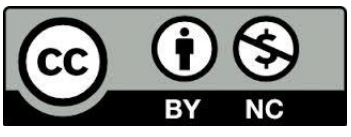

This work is licensed under a Creative Commons Attribution-NonCommercial 3.0 Unported License 


\section{Disclosure and HIV transmission}

\section{Samantha Ryan, Newcastle Law School}

Abstract:

This paper examines the various approaches to disclosure of HIV infected status identified by the Law Commission in its Scoping Consultation Paper on Reform of Offences against the Person. It argues against the imposition of a general duty to disclose in all circumstances, and further suggests that a requirement for disclosure cannot be justified when there is a low risk of transmission. It suggests that the better approach to disclosure is to be found by combining the remaining two Law Commission proposals. This would mean that whether a person was justified in exposing another to the risk of HIV infection without disclosing their HIV positive status would be a matter for the jury and a key factor relevant to the jury's consideration in this regard would be the level of risk of transmission involved.

Keywords: HIV transmission, disclosure, duty, criminal liability, significant risk, justifiable nondisclosure

\section{Introduction: Background and the Scoping Paper}

The issue of bringing disease transmission, whether through sexual intercourse or otherwise, within the scope of non-fatal offences against the person had previously been considered by the Law Commission in its 1993 Report, Legislating the Criminal Code: Offences against the Person and General Principles. ${ }^{1}$ In that report the Law Commission concluded that disease transmission was simply another way of causing injury and should be included within the remit of offences against the person. ${ }^{2}$ The Law Commission's proposals referred to intentionally causing serious injury, recklessly causing serious injury or intentionally or recklessly causing injury; with the transmission of disease potentially falling within all 3 offences. The Home Office in its Consultation Paper Violence: Reforming the Offences against the Person Act, 1861, suggested this was an inappropriate extension of the law and proposed that only intentional transmission of disease should be criminalised. ${ }^{3}$ The draft Bill accompanying the Home Office Consultation Paper accordingly provided that 'injury' did not include anything caused by disease, except for the purposes of the offence of intentionally causing serious injury. ${ }^{4}$

Two cases, Dica ${ }^{5}$ and Konzani, ${ }^{6}$ however moved the law far beyond this position in relation to criminal liability for the transmission of HIV (and it would seem other serious sexually transmitted infections). ${ }^{7}$ It is now possible for the reckless sexual transmission of HIV to be prosecuted under s.20 of the Offences Against the Person Act, 1861. It is in this new legal order that the Law Commission, in its Scoping Consultation Paper, Reform of Offences Against the Person, had to reconsider the application of the law governing offences against the person to the transmission of disease and in particular to the transmission of HIV and other sexual infections through consensual sexual intercourse. ${ }^{8}$ The Law Commission considered adopting the scheme in the Draft Bill as originally proposed. This would effectively reverse the decision in Dica and would accord with a sizeable body of opinion which believes criminalisation is only ever justified in the case of intentional transmission. ${ }^{9}$ The Law Commission rejected this option on the grounds that it would leave an undesirable gap in the law. ${ }^{10} \mathrm{~A}$ second, and it would seem preferred possibility put forward, was to 
modify the Draft Bill to reflect the current law so that transmission of disease would be an offence whether caused intentionally or recklessly. ${ }^{11}$ The Law Commission recognised that such an approach raises many concerns: it may discourage testing, discourage openness with doctors, encourage people to assume their sexual partner is not infected in the absence of disclosure, lead to intrusive investigations regarding past sexual history and reinforce stigma. ${ }^{12}$ Ultimately the Law Commission contended that excluding disease from the definition of injury was not the answer to these concerns and suggested that if it was deemed appropriate to exclude the transmission of disease by consensual sexual intercourse that this could be done by way of a specific exemption. ${ }^{13}$

Having set the terrain for the inclusion of disease transmission within the offences against the person, the Law Commission came to the issue of disclosure. It recognised that in order to properly address the issue of liability for disease transmission, particularly in the context of sexual transmission of disease, a clear position regarding disclosure is required. The Law Commission identified three possible approaches to disclosure: (1) D should be bound to disclose facts indicating a risk of infection only if the risk is significant; (2) $D$ should be bound to disclose facts indicating a risk of infection in all circumstances; or (3) Whether $D$ was justified in exposing $V$ to that risk without disclosure should be a question for the jury. ${ }^{14}$ Before considering these approaches to disclosure it is worth setting out the current position in English law regarding disclosure and criminal liability for HIV transmission.

\section{Current Law on HIV Transmission and Disclosure}

In the case law to date there has been no substantive analysis or argument regarding whether there should be a legally recognised duty of disclosure. Instead disclosure has been discussed somewhat obliquely; in the context of whether consent can afford a defence to a charge of reckless transmission, and how non-disclosure relates to a defendant's ability to claim an honest belief in consent. Although never explicitly stated in either Dica or Konzani it seems clear that there is, as yet, no recognised legal duty to disclose one's HIV status to ones' sexual partner in England and Wales. Yet it is submitted that the law has come very close to imposing such an obligation by allowing for consent or an honest belief in consent to operate as a defence in cases of non-disclosure in very limited circumstances. In Dica the defendant, knowing that he was HIV positive, had unprotected sex with two women, both of whom subsequently contracted the infection. Having ruled out the possibility of a rape charge, the ultimate issue for decision was whether it was possible for the complainants' consent to the risk of infection to provide a defence to the section 20 charge of maliciously inflicting grievous bodily harm. ${ }^{15}$ The Court, per Lord Justice Judge, accepted that whilst consent could not operate as a defence to the deliberate infliction of HIV, consent could operate as a defence where the complainants were willing to run the risk of infection. ${ }^{16}$ It was recognised that the taking of risks, whether related to disease transmission or unintended pregnancy, had always been a feature of consensual adult sexual relations and that neither society nor the law had sought to intervene and criminalise such behaviour in the past. ${ }^{17}$ This level and degree of interference with personal autonomy, if it was to occur, was ultimately a matter for Parliament and not the courts. ${ }^{18}$

Having decided that consent could provide a defence, the Court had to then consider whether there could be consent to the risk of disease transmission in circumstances where the defendant had not disclosed his infection to his sexual partner. Judge $L J$ stated that if the defendant concealed the truth 
about his condition and kept his partners in ignorance of it, there was no reason for his sexual partners to think they were running a risk of infection and they were therefore not consenting to that risk. ${ }^{19}$ This seems to suggest that disclosure of HIV status must be made before consent can provide a defence. However, by recognising that 'the ultimate question is not knowledge, but consent'; the court appeared to accept that in certain circumstances the defence of consent might apply, notwithstanding the accused's failure to disclose his condition. ${ }^{20}$ Such an approach seems highly sensible. It is possible for individuals to be aware of the risk of HIV transmission without disclosure by their sexual partner. Accordingly, it is arguable that a person who, with such knowledge, willingly chooses to engage in unprotected or risky sexual relations by that very fact consents to the risk of infection..$^{21}$ That the Court was cognisant of this possibility could arguably be derived from its statement: 'at one extreme there is casual sex between complete strangers, sometimes protected, sometimes not, when the attendant risks are known to be higher' (my emphasis). ${ }^{22}$

Overall however it must be said that the court in Dica leaned strongly towards a requirement of disclosure in virtually all circumstances. This is evidenced in the Courts final remarks where it was reiterated that consent to sexual intercourse was not of itself to be regarded as consent to the risk of consequent disease; and that it was unlikely that a person would consent to a risk of major illness if they were ignorant of that risk. ${ }^{23}$ This substantially limits the extent to which general knowledge of the risks associated with unprotected or risky sex can form the basis of a valid consent to the risk of transmission. ${ }^{24}$ The court further stated that the effect of its judgment was 'to remove some of the outdated restrictions against the successful prosecution of those who, knowing that they are suffering HIV or some other serious sexual disease, recklessly transmit it through consensual sexual intercourse, and inflict grievous bodily harm on a person from whom the risk is concealed and who is not consenting to it' (my emphasis). ${ }^{25}$ Weait suggests that when read together these statements give rise to an implicit assumption that the source of knowledge for the person who must consent to the risk of transmission is the person who may transmit HIV to them. ${ }^{26}$ When the infected person does not directly disclose their infected status to their sexual partner prior to commencing sexual relations it seems highly unlikely that a defence of consent or of honest belief in consent will succeed. The effective need for disclosure is again evidenced by Lord Woolf's summary of the Dica decision in the case of $R v$ Barnes. ${ }^{27}$ Lord Woolf stated that a person would be guilty of a section 20 offence for the transmission of HIV if, being aware of his condition, he has sexual intercourse without disclosing the fact of his infection. On the other hand, he would have a defence if he had made this partner aware of his condition, who with that knowledge consented to sexual intercourse with him because she was prepared to accept the risks involved. ${ }^{28}$ Lord Woolf's interpretation, which was approved by Judge $L J$ in Konzani, firmly places the spotlight on the behaviour of the defendant and whether he disclosed or not. ${ }^{29}$ Examination of the complainant's knowledge or possible acceptance of risks is linked almost entirely to the issue of whether there has been disclosure by the accused. ${ }^{30}$

The Court in Konzani continued this drift towards the creation of a legal duty to disclose. In Konzani it was made clear that for consent to operate as a defence it had to be 'informed'. ${ }^{31}$ Judge $L$ stated that concealment of HIV positive status almost inevitably meant that one's partner was deceived and that consent given in such circumstances was not properly informed. This approach to consent was justified in terms of protecting the personal autonomy of the deceived or uninformed sexual partner: 'If an individual who knows that he is suffering from the HIV virus conceals this stark fact 
from his sexual partner, the principle of her personal autonomy is not enhanced if he is exculpated when he recklessly transmits the HIV virus to her through consensual sexual intercourse'.$^{32}$ The court went further and held that whilst an honest belief in consent would provide a defence, a failure to disclose was 'incongruous with honesty, or with a genuine belief that there was an informed consent'. ${ }^{33}$ This position was again justified by reference to personal autonomy; 'personal autonomy is not normally protected by allowing a defendant who knows that he is suffering from the HIV virus which he deliberately conceals, to assert an honest belief in his partner's informed consent' ${ }^{\prime 34}$ The Court further held that there was a distinction between taking a risk of the various and potentially adverse consequences of sexual intercourse and giving an informed consent to the risk of infection with a fatal disease. ${ }^{35}$ With respect, this distinction is somewhat artificial. ${ }^{36}$ Indeed Mawhinney describes this reasoning as 'semantics'; arguing that 'consent to a risk naturally includes consent to the harm if the risk comes to fruition' ${ }^{37}$ As it stands the court in Konzani creates a situation in which those who willingly run a risk of infection are not held accountable or responsible for the consequences of doing so. ${ }^{38}$ By prioritising sexual autonomy over sexual responsibility it suggests, contrary to most HIV prevention campaigns, that we are not responsible for our own health. ${ }^{39}$

However, the Court stopped just short of creating an absolute duty to disclose by recognising the possibility that in certain circumstances informed consent to the risk of transmission may be given notwithstanding the defendant's failure to disclose. The Court gave two examples of when this possibility may arise; an individual with HIV may develop a sexual relationship with someone who knew him while he was in hospital receiving treatment for the condition, or alternatively a third party may disclose the fact of a person's HIV status. In both of these situations the Court felt it would be possible for an accused to assert the honest belief in consent defence..$^{40}$ It must be recognised that the examples provided by the court in Konzani are extremely limited and effectively are situations in which there is disclosure (either through context or a third party), albeit not by the infected individual. ${ }^{41}$ Once again it must be recognised that the thrust of the decision is that disclosure by a partner is the only relevant source of knowledge for the purposes of being able to give an informed consent to the risk of transmission, despite the fact that there are a myriad of other ways in which a person can gain knowledge of possible risks and make a conscious and willing decision to run that risk. ${ }^{42}$ As Weait observes it effectively denies the possibility that a person to whom disclosure is not made may still be sufficiently knowledgeable about the risk of transmission to warrant the conclusion that he or she did in fact consent' ${ }^{43}$

Given the overall push towards disclosure in Dica and Konzani, both for finding consent to be informed and for supporting a claim of honest belief in consent, it seems difficult to accept Cherkassky's claim that informed consent is currently the victim's responsibility and leaves the defendant with no responsibility to divulge his status. ${ }^{44}$ On the contrary, it seems that in only extremely limited circumstances will an informed consent or an honest belief in consent be found to exist in the absence of direct disclosure by the infected person. In short, there is an 'effective' duty to disclose in order to avoid criminal sanction. ${ }^{45}$ Having set out the current approach to disclosure and HIV transmission carved out by the Courts in England and Wales it is now useful to consider the approaches to disclosure put forward by the Law Commission. 


\section{Approaches to Disclosure}

The issue of non-disclosure in the context of HIV transmission is highly contentious. ${ }^{46}$ The Law Commission focused on one particular aspect of this difficult area - whether disclosure is required when the risk of transmission is low, either because the infected person is using a condom, or is undergoing treatment which reduces the viral load to an undetectable level. ${ }^{47}$ This is an issue which has not yet been considered by UK courts. Instead cases have been concerned with conduct that poses a high risk of transmission (mainly repeated instances of unprotected sexual intercourse). ${ }^{48}$ It is currently unclear whether condom use would preclude a finding of recklessness in the absence of disclosure. In Dica, Lord Justice Judge indicated that use of a condom may be relevant to a jury's consideration of the issue of recklessness. ${ }^{49}$ The Crown Prosecution Guidelines suggest that proper use of appropriate safeguards to prevent transmission will render a finding of recklessness highly unlikely. ${ }^{50}$ In relation to viral load it would seem, although it is not entirely clear, that the Law Commission is considering instances of unprotected sex where the person infected has an undetectable viral load. The issue of viral load has not yet been the subject of judicial consideration in this jurisdiction and the Crown Prosecution Guidelines suggest that evidence of this kind be approached with caution. ${ }^{51}$ The Law Commission as already indicated identified three possible approaches to disclosure in the context of low risk activity: (1) D need only disclose facts indicating a risk of infection if the risk is significant, (2) D should be bound to disclose facts indicating a risk of infection in all circumstances or ( 3 ) whether $D$ was justified in exposing $V$ to a risk of transmission without disclosing should be a question for the jury. It is proposed to address the second of the three possibilities first - a general duty to disclose.

\section{A General Duty to Disclose}

It is accepted that the moral/ethical case for disclosure of HIV positive status to prospective sexual partners is strong. This does not necessarily mean however that the case for criminal liability in the absence of disclosure is made out. Not every immoral or reprehensible act is subject to criminal sanction. Before deciding whether a legal duty to disclose should exist a balancing of rights and interests of both parties to a sexual encounter, which takes account of policy and public health goals and principles, should be conducted. Only once this has been undertaken will it be possible to determine whether a duty to disclose should exist in all circumstances, including where the risk of transmission is low due to viral load or condom use.

Both infected persons and their sexual partners can invoke autonomy and privacy rights when considering arguments for and against a legal duty to disclose. ${ }^{52}$ Infected individuals' rights to privacy and autonomy are clearly curtailed by a legal duty to disclose HIV infected status. A requirement for disclosure in all cases means that once a person has been diagnosed, that person is duty bound to warn all prospective sexual partners however insignificant the risk of transmission might be..$^{53}$ This possibly goes too far. It arguably places too little weight on the right and interests of the infected person to privacy and sexual expression. ${ }^{54} \mathrm{~A}$ duty to disclose, even in cases of low risk may be a disproportionate interference with an infected person's sexual freedom. Furthermore, given the stigma and discrimination that can attach to those with a HIV positive status, an infected individual has a strong interest in protecting the confidentiality of their medical diagnosis. There is no guarantee of confidentiality when a person does disclose and there would always be a risk that a 
sexual partner, if informed, would share this information with others. ${ }^{55}$ In short it is argued that principles of autonomy militate in favour of protecting the infected person's privacy rights and against the imposition of a duty to disclose ${ }^{56}$ Of course these arguments may be challenged on a number of grounds. The infected individuals' rights of autonomy and privacy are not absolute and have to be balanced against the rights and interests of their sexual partner. Further, respect for individual autonomy does not extend to behaviour than can cause serious harm to others and privacy interests of those infected may be outweighed by the risk to life and health of their sexual partner. ${ }^{57}$ It is worth noting that these counter arguments are at their strongest when considering conduct which poses a serious risk of transmission and that they may be less weighty, and accordingly autonomy arguments for those infected may prevail over other interests, where transmission risks are low.

Of course, sexual partners can also make the case for disclosure based on notions of personal autonomy. It could be argued that disclosure allows those considering a sexual relationship to make an informed, autonomous choice about whether or not to run the risk of infection. Failure to disclose precludes the sexual partner from exercising their autonomy in an informed and meaningful way. ${ }^{58}$ As Gostin and Hodge observe 'while a partner is free to consent or refuse sex, that choice is meaningless unless it is made with reasonable knowledge of the risks'. ${ }^{59}$ Similar reasoning was used by the Court of Appeal in the case of Konzani (as discussed above). It is argued that this reasoning is not altogether sound. It makes an assumption that the only source of knowledge regarding risks of HIV transmission for sexual partners is the person infected. However as already argued, knowledge of risk of transmission may be derived from a number of possible sources. A sexual partner may be ignorant of a partner's HIV positive status in the sense that this information has not been directly disclosed to them, but they may still have full awareness of possible risks associated with sexual intercourse and in particular with the various risks associated with unprotected sexual intercourse. In other words a failure to disclose by the infected partner does not necessarily preclude an autonomous choice. ${ }^{60}$ Where a person willingly runs the risk of infection they should be held accountable for the consequences of doing so (or at least they should not be able to place all the blame on their sexual partner if transmission occurs). ${ }^{61}$ This would better reflect the public health approach to reducing transmission which provides that we are all responsible for our own health and that we should all take adequate measures to protect ourselves. ${ }^{62}$

Admittedly such reasoning does not sit easily with traditional approaches to criminal liability where responsibility for transmission is understood as belonging solely to the infected individual who, with knowledge of their health status and risks of transmission, causes another to become infected. ${ }^{63}$ As Cornett observes: 'Most crimes require examining only the accused's agency in bringing about a harmful result; the victims actions are largely or totally irrelevant to the initial decision to criminalise'. ${ }^{64}$ It is arguable however that this approach, which focuses on individualist ideas of liability, is not suited to cases of consensual sexual intercourse in which transmission occurs. ${ }^{65}$ As Weait suggests: 'we must question whether it is right to attribute sole responsibility to and punish the person who transmits the virus, when that would not have happened but for the other person's willingness to accept that risk'. ${ }^{66}$ It may be more appropriate in such cases to base decisions as to criminal liability on notions of shared or mutual responsibility. This would allow for fairer assessments of culpability and responsibility and would be more in line with the public health message about taking responsibility for our own personal health. Mawhinney is critical of this shared responsibility approach and challenges the claim that the victim may be partly to blame for not 
asking personal questions about their partner's sexual health. ${ }^{67}$ Indeed for many it is the infected persons' actual knowledge of their status that decisively tips the balance in favour of placing greater responsibility on them. ${ }^{68}$ Such reasoning may be hard to resist. However, whether this responsibility can only be met through disclosure or whether it can be satisfied by using precautions or requires both is not always clear. For instance Mawhinney contends that it is solely the responsibility of those who are ill to disclose the fact of their HIV positive status. ${ }^{69}$ Cornett suggests that because the diagnosed individual has the most complete information regarding his medical status it is right that he bears the ultimate burden of disclosure and of taking adequate precaution to protect his partners. ${ }^{70}$ The Crown Prosecution Guidelines make clear that where one partner knows there is a risk of transmitting an infection and the other does not know; it is only reasonable that the partner who knows should have the major share of responsibility for avoiding the risk. It seems possible, given the additional guidelines concerning use of precautions and recklessness, that this responsibility can be met by taking precautions without disclosing. ${ }^{71}$ Isabel Grant would also allow use of precaution to operate as a substitute for disclosure. ${ }^{72}$ For others however the use of precautions cannot replace the need for full disclosure. Ciccarone et al suggest that the use of unilateral risk reduction strategies is ethically indefensible as it does not allow the sexual partner the opportunity of deciding what level of risk is acceptable to them. ${ }^{73}$ Field and Sullivan argue that the use of precautions ought not to be a defence unless the person infected has also informed his partner. ${ }^{74}$ Flaherty opines that allowing condom use to operate as a defence in the absence of disclosure effectively sanctions deceit. ${ }^{75}$

Two further considerations may help resolve the question of whether the use of precaution in the absence of disclosure should be sufficient to evade criminal liability. First, difficulties surrounding disclosure should be recognised. Disclosure can bring with it a multitude of negative consequences discrimination, stigma, rejection, abandonment or even personal physical harm. ${ }^{76}$ It is unfair to assume that non-disclosure is due to moral cowardice or prioritising one's own sexual needs over another's. ${ }^{77}$ Not all non-disclosers are sexual pariahs. Indeed some studies have shown that people living with HIV who do not disclose only practice low risk sexual activity (i.e. use a condom or engage in oral sex).$^{78}$ Participants in these studies suggested that disclosure was not required because they were not putting their sexual partners at risk or were only exposing them to very low risk. Moreover, for many people it is often easier and safer to take precautions than it is to disclose. ${ }^{79} \mathrm{~A}$ second consideration is the fact that, short of abstinence, condom use is one of the best ways of preventing onward transmission of HIV. ${ }^{80}$ It would seem that allowing condom use to negate recklessness, even without disclosure, adequately respects the interests of those infected to sexual expression and privacy, the bodily integrity of sexual partners by seeking to protect them from harm and satisfies the public health priority of preventing the spread of HIV. ${ }^{81}$ Therefore it is argued that the use of precautions should be considered to lower the risk of transmission sufficiently so that no criminal liability would arise and that careful and consistent condom use would negate the need for disclosure.

A final point to consider before concluding on the appropriateness or otherwise of a general duty to disclose is to consider whether such a duty would be effective in deterring risky behaviour and reducing incidences of transmission? A number of observations can be made here. Firstly, it has been found that disclosure does not always lead to safer sex practices..$^{82}$ If the ultimate aim is to limit the spread of disease then greater attention should be placed on ensuring condom use rather than disclosure. This is all the more important given that most instances of transmission occur when the 
infected person has not been medically diagnosed. ${ }^{83}$ Secondly, it is not clear that the threat of criminal sanction is effective in changing behaviours which frequently occur in the heat of the moment' or under the influence of intoxication. ${ }^{84}$ Thirdly, it assumes that people living with HIV would have knowledge and understanding of the legal rules regarding disclosure and it also presumes that those infected would prioritise concerns regarding legal liability over other concerns such as privacy, safety and sexual expression. ${ }^{85}$ Overall, whilst it is recognised that a general rule of disclosure would have the benefit of clarity and simplicity, it is suggested that such an approach cannot be justified on grounds of policy or principle and would cast the net of criminal liability far too widely when the risk of transmission is low. ${ }^{86}$ As the Law Commission recognises in the Scoping Paper: 'consent to intercourse implies consent to the normal level of risk, and in the cases with which we are concerned (use of condom and undetectable viral load the level of risk is no more than normal, and may be less'. ${ }^{87}$

\section{Significant Risk and Duty to Disclose}

Having rejected the idea of a general duty to disclose in all circumstances it is now appropriate to consider the Law Commission's proposal that a duty to disclose should exist when the risk of transmission is significant. There is support for this approach in the academic commentary. Flaherty suggests that a 'significant risk of harm in a sex act awakens the duty to disclose one's HIV positive status' ${ }^{88}$ Cornett states that the infected person should disclose when his/her activity poses a significant risk of serious bodily harm. ${ }^{89}$ This suggestion does appear to strike a better balance between the rights and interests of those infected and the right and interests of their sexual partners. A high risk of transmission arguably justifies placing the burden of disclosure upon the diagnosed individual on the grounds that the right to bodily integrity and health of the sexual partner outweighs the infected individual's rights to privacy and sexual freedom. Confining criminal sanction to conduct which poses a significant risk of transmission would also mean that only the most culpable behaviour is punished and the risk of over-criminalisation is avoided. ${ }^{90}$

The need for clarity regarding what is meant by a 'significant risk' is essential. In this regard lessons can be learned from Canada. ${ }^{91}$ The Canadian Supreme Court in Cuerrier ruled that non-disclosure of HIV positive status would constitute fraud negating consent to sexual activity where there was a 'significant risk of serious bodily harm'. ${ }^{92}$ Unprotected intercourse was categorised as posing a significant risk of bodily harm..$^{93}$ It was also stated that the extent of the duty to disclose was linked to the level of risk and that where the risk of bodily harm was not 'significant' the duty to disclose did not arise. ${ }^{94}$ Justice Cory, writing for the majority, stated obiter that 'the careful use of condoms might be found to so reduce the risk of harm that it could no longer be considered significant' and therefore there would be no obligation to disclose. ${ }^{95}$ In the years following the Cuerrier decision there was much uncertainty regarding the test laid down. ${ }^{96}$ Some courts interpreted Cuerrier as providing that there could be no liability in cases of protected sexual intercourse. ${ }^{97}$ Yet in other cases it was made clear that it was still possible for non-disclosure in the context of protected sexual intercourse to give rise to liability. ${ }^{98}$ On other occasions the issue of condom use was ignored altogether, and the focus was solely on whether there had been disclosure. ${ }^{99} \mathrm{~A}$ further difficulty was the lack of a uniform understanding of what constituted a significant risk. For example in Edwards, the Crown acknowledged that a prosecution could not have been based on an act of oral sex alone, given the low risk of transmission. ${ }^{100}$ Yet in Agiza unprotected oral sex formed the basis of a conviction for aggravated sexual assault. ${ }^{101}$ In $D C$, the trial judge convicted the accused of aggravated 
sexual assault and sexual assault where the risk of transmission was said to be 1 in 10,000, finding that any risk of transmission is sufficient because of the seriousness of the potential harm. ${ }^{102}$ The Quebec Court of Appeal overturned this finding and acquitted the accused because the risk of transmission was so low as to be insignificant. ${ }^{103}$ Essentially jurors were presented with expert evidence and statistics, which differed vastly from case to case, and from this had to determine whether the risk of transmission was significant and whether disclosure was necessary. As Grant observes: 'the cases reveal, at best, the lack of precision in assessing risk and, at worst, blatant inconsistency regarding the acceptable level of risk'. ${ }^{104}$ There was widespread concern that the decision in Cuerrier and its subsequent interpretation had resulted in over-criminalisation of persons with HIV who had not disclosed their status. ${ }^{105}$

It was hoped that the Supreme Court of Canada in $R v$ Marbior and $R v D C$ would address these concerns by providing clarity regarding the meaning of significant risk and when disclosure was required. ${ }^{106}$ The Supreme Court in making its decision had the benefit of the latest medical research regarding inter alia the likelihood of transmission, the relevance of viral loads and HIV treatments (much of which was not known at the time of the Cuerrier decision). The Supreme Court in Marbior and $D C$ indicated that a significant risk of bodily harm exists when there is a 'realistic possibility' of transmission. ${ }^{107}$ The Court further explained that anything 'non-negligible' is realistic. ${ }^{108}$ Therefore, a realistic possibility of transmission was said to exist during vaginal sexual intercourse unless two conditions were met: first the accused must have a low viral load at the time of the encounter and secondly condoms must be used during intercourse. ${ }^{109}$ Interestingly the Canadian Supreme Court claimed that the realistic possibility of transmission standard avoided 'setting the bar for criminal conviction too high or too low' and struck the appropriate balance between the complainant's autonomy and the need to avoid over-criminalisation. ${ }^{110}$ Yet, by insisting on both low viral load and condom use the Court's 'realistic possibility' test is in reality a 'no-risk test'. ${ }^{111}$ Medical evidence shows that when condoms are used for vaginal intercourse the rates of transmission are approximately 1 in 10,000 for the non-infected female sexual partner and 1 in 20,000 for the male partner. ${ }^{112}$ It has also been found that a low or undetectable viral load makes transmission of HIV extremely unlikely. ${ }^{113}$ Where a viral load is suppressed as a result of HAART, the risk of transmission has been found to be reduced by 89 to $96 \% .{ }^{114}$ It is unclear how these levels of risk were seen to present a realistic possibility of transmission. Indeed it could be argued that either condom use or low viral load reduces the level of risk to such a degree that disclosure is not required. Unfortunately the Supreme Court did not engage with the medical evidence presented making it difficult to understand where it chose to draw the line for criminal liability and disclosure. ${ }^{115}$ It seems post Marbior and $D C$ that the word 'significant' from Cuerrier has been stripped of all meaning. ${ }^{116}$ Further, it seems that extremely low levels of risk can be construed as posing a realistic possibility of transmission. ${ }^{117}$ The decision in Marbior and $D C$ rather than restricting the reach of Cuerrier continues and in fact extends the over-criminalisation of non-disclosure of HIV status.

Whilst the Canadian experience highlights the potential dangers of adopting a 'significant risk' test, it is not suggested that such a test is unworkable. Moreover, given the vital role a 'significant risk' of transmission test can potentially play in confining criminal liability to the most culpable cases and achieving a better balance between the rights and interests of people living with HIV and their sexual partners; it is essential that a workable and fair understanding of the concept of significant risk is found. To achieve this it is necessary to firstly recognise that infection with HIV is a serious harm, notwithstanding advancements in medical treatments. However it is only by considering the 
seriousness of harm together with the likelihood of the harm occurring, that it is possible to determine whether the risk is significant. The criminalisation of a risk of even a severe harm is difficult to justify if the actual likelihood that it will occur is very small. ${ }^{118}$ Secondly the definition of 'significant risk' must be linked to scientific evidence on the likelihood of transmission. It is suggested that there are two possible approaches here - the 'high risk activity approach' and the 'statistical data' approach. The 'high risk activity' approach is by far the simpler and more straightforward of the two, relying on classifications of sexual activity as either high or low risk advanced in the medical literature. Essentially conduct that has been classified as high risk activity would be treated in law as posing a significant risk of transmission and accordingly trigger the need for disclosure. ${ }^{119}$ For example insertive or receptive penile-anal or penile-vaginal intercourse without a condom and receptive insertion of shared sex toys is considered high risk activity and would therefore be treated as posing a significant risk of transmission. Protected or unprotected oral sex and sex with a condom is considered low risk activity and would accordingly fail to meet the significant risk threshold for criminal liability and fail to trigger a disclosure requirement. Undetectable or low viral load could arguably be considered equivalent to other low risk activity. ${ }^{120}$

An alternative way of approaching the significant risk concept is to look at statistical data regarding the per-act risk of transmission. This approach is necessarily more complicated and as the Canadian experience has shown it often involves the use of expert evidence, conflicting data regarding levels of risk and different interpretation of such data by various juries. ${ }^{121}$ Yet it would clearly offer a more nuanced understanding of the various risks associated with different sexual activity. For instance, it was stated above that unprotected vaginal intercourse is a high risk activity. It has been shown however that the risk of transmission from an infected male to a female $(1 \mathrm{in} 1,250)$ is far greater than the risk of transmission from an infected female to male partner $(1$ in 2,500$)$ possibly creating scope for a gendered approach to significant risk in the context of this type of sexual activity. ${ }^{122}$ Unprotected anal intercourse is widely regarded as high risk. However HIV is more likely to pass from a HIV-positive insertive partner to his receptive partner ( 1 in 122 risk of transmission) than from a HIV-positive receptive partner to his insertive partner (1 in 1,666 risk); again creating the possibility for different approaches to a sexual activity depending on the role the HIV-positive partner plays. ${ }^{123}$ Of course a jury may well decide in both instances that the levels of risk whilst different are still significant.

The Canadian case of $R v J T$ highlights the impact adoption of a 'high risk activity' approach or a 'statistical data' approach to the meaning of significant risk can have on criminal liability. ${ }^{124}$ In JT the accused failed to disclose his HIV-positive status to his male partner. It was found that there were 3 acts of unprotected anal intercourse and that the accused was always the receptive partner. ${ }^{125} \mathrm{At}$ the preliminary hearing the per-act risk of transmission was said to be 1.5 in $10,000 .{ }^{126}$ The accused challenged his committal for trial on the grounds that the Crown had failed to provide evidence of a significant risk of transmission. The British Columbia Court of Appeal rejected that argument and, adopting a 'high risk activity' approach, gave preference to the evidence of the HIV/AIDS specialist who stated that anal intercourse without a condom is a high risk activity. ${ }^{127}$ No consideration was given to the respective roles of the accused and the complainant within the sexual activity. When remitted for trial, the trial judge adopted a 'statistical data' approach and found on the basis of the expert evidence that the cumulative risk of transmission for the 3 unprotected acts of anal intercourse was approximately 12 in 10,000 or $0.12 \%{ }^{128}$ This level of risk was not, according to the trial judge, significant enough to meet the Cuerrier test. ${ }^{129}$ It is clear that either approach has 
advantages and disadvantages; a full exploration of which is outside the scope of this paper. What is essential to recognise at this stage is the importance of having a clear understanding of what constitutes a significant risk and of the various ways in which a definition could be approached. ${ }^{130}$

However, whilst in favour of using a significant risk test it is felt that to impose a duty to disclose may be a step too far. It is recognised that in some high risk sexual activity situations (and these would be fairly limited) the risks associated with disclosure may be extremely high and the ability to insist on use of precautions or safer sex may be extremely limited. ${ }^{131}$ In such situations, a duty to disclose imposes an unfair burden on people who are already seriously disadvantaged both by their HIV infection and their vulnerability to violence or abuse or lack of power to negotiate safe sex. ${ }^{132} \mathrm{~A}$ fairer solution would be to treat high risk activity as giving rise to a rebuttable presumption of disclosure. In other words, the expectation for disclosure increases when the person infected is engaging in high risk activity but that it will ultimately be for the jury to determine whether nondisclosure is justifiable or not in any given situation. It would therefore be harder to claim nondisclosure was justifiable in the context of high risk activity but not impossible. This effectively combines the first and third proposal put forward by the Law Commission.

\section{Justifiable Non-Disclosure and Significant Risk}

The third proposal put forward by the Law Commission in its Scoping Paper was that whether D was justified in exposing $V$ to a risk of transmission without disclosing should be a question for the jury in each particular case. There is merit to such an approach provided, as already indicated, the need for disclosure is linked to the level of risk and furthermore that there is a clear understanding of what amounts to a significant risk. This would mean that unless facts are contested, a judge would be able to tell the jury that the conduct in question posed a significant risk and then it would be for the jury to determine whether non-disclosure was justifiable or not. Where facts are contested the judge should be able to provide the jury with a detailed description of what in law amounts to a significant

risk. To leave the assessment of risk entirely to the jury without such guidance would lead to uncertainty as to how risk was being assessed, inconsistent verdicts and a lack of clarity in the law. ${ }^{133}$ If liability for HIV transmission is to remain within the offences against the person, it is suggested that it is possible to incorporate the above approach to disclosure within a proper understanding of recklessness, which recognises that it is only unreasonable or unjustifiable risks that are deserving of criminal sanction. ${ }^{134}$ Interestingly the Court of Appeal in Konzani did bring the issue of non-disclosure within the remit of recklessness. The Court described the reckless behaviour of the defendant in Dica, as resting on the allegation that 'knowing he was suffering from HIV and its consequences and knowing the risk of its transmission to a sexual partner, he concealed his condition from the complainants'. ${ }^{135}$ In a similar fashion in $R \vee$ Golding the Court stated that a jury could infer recklessness on the part of the accused from the fact that he had knowledge of his herpes infection prior to meeting the complainant and his acknowledgement that he should have told the complainant about his condition prior to starting a sexual relationship with her. ${ }^{136}$ Quite simply the defendant in Golding was reckless because he knew there was a risk, did not disclose it and went ahead and anyway ${ }^{137}$ The problem with both of these cases is that the issue of justifiability of risk was not considered. 
It is recognised there is very little authority relating to this particular element of recklessness. ${ }^{138}$ However, the Law Commission in its Scoping Paper describes the test of recklessness as 'awareness without objective justification'. ${ }^{139}$ Admittedly it would be extremely difficult to make an argument that non-disclosure in cases like Dica, Konzani and Golding was justified; particularly given the fact that the defendants engaged in repeated unprotected sexual intercourse, a high risk activity, with full knowledge and understanding of their condition and the risks of transmission. It is submitted however that it is not acceptable to simply assume that non-disclosure is unjustifiable in all circumstances when a legal duty to disclose has not been imposed. Instead it is argued that if nondisclosure is to form part of the assessment for a finding of recklessness then the question of justifiability of non-disclosure must be explicitly considered.

\section{Conclusion}

The Law Commission is right to assert that any approach to criminalisation of the reckless sexual transmission of HIV must deal directly with the issue of disclosure. However, an essential part of formulating the correct legal response to the issue of disclosure requires a realistic assessment of its overall importance in terms of preventing HIV transmission. It has been argued here that disclosure is not always necessary to enable an autonomous choice regarding the type of sexual activity one partakes in. Moreover, it has been asserted that a person can engage in responsible and respectful sexual activity in the absence of disclosure and that an emphasis on condom use over disclosure would do more to reduce incidences of infection. ${ }^{140}$ On the basis of this understanding of disclosure it is suggested that a general duty to disclose in all circumstances cannot be justified. Whilst it is recognised that arguments requiring disclosure are at their most weighty and persuasive where the risk of transmission is significant, it is nevertheless contended that the imposition of a duty to disclose goes too far. A more just approach is to recognise that in cases of significant risk there is an expectation that disclosure is necessary to avoid criminal sanction but ultimately a jury would determine whether non-disclosure was reckless in the given circumstances. This would effectively combine two of the Law Commission's suggested approaches to disclosure. When it comes to activity that poses a low risk of transmission, it is suggested that arguments for disclosure are less weighty and that non-disclosure in such circumstances should never give rise to criminal liability. In order to accommodate this approach, or indeed, any approach to disclosure within section 20 of the Offences Against the Person it will be necessary to give full breadth to the concept of justifiability of risk-taking within the broader concept of recklessness. ${ }^{141}$ Of course it may be far preferable to devise a specific HIV-transmission offence but that is work for another day and another Scoping Paper.

\footnotetext{
*Lecturer in Law, Newcastle University

${ }^{1}$ Law Com No 218

${ }^{2}$ Ibid. at paras. 5.15, 5.17

${ }^{3}$ Home Office CP 1998 at paras 3.16, 3.18 and 3.19

${ }^{4}$ Draft Bill (1998) Clause 15

5 [2004] QB 1257

6 [2005] 2 Cr App r 14

7 See Golding [2014] EWCA Crim 889 a case involving the transmission of genital herpes

${ }^{8}$ Law Commission, Reform of Offences against the Person: A Scoping Consultation Paper No 217 (2014)

(hereinafter The Scoping Paper).
} 
${ }^{9}$ See generally M. Weait, Intimacy and Responsibility: The Criminalisation of HIV transmission (RoutledgeCavendish: Abingdon, Oxon, 2007); R. Elliot, Criminal Law, Public Health and HIV Transmission: A Policy Options Paper, June 2002 from the Joint United Nations Programme on HIV/AIDS; UNAIDS, UNAIDS Policy Brief: criminalisation of HIV transmission (Geneva: Switzerland,2008); C. Dodd et al, 'Grievous Harm? Use of the Offences Against the Person Act 1861 for sexual transmission of HIV- Briefing Paper, Sigma Research 2005.

${ }^{10}$ Above $n .8$ at para 6.68

${ }^{11}$ Above n.8 at para 6.69 and 6.70. This is seen as 'the safer course'.

${ }^{12}$ Above n.8 para 6.78

${ }^{13}$ Above n.8 para 6.79

${ }^{14}$ Above $n$ 8. para 6.98

${ }^{15}$ Above n.5, para 39. It was found that there was consent to sexual intercourse and that consent was not vitiated by the defendant's deception/non-disclosure of HIV positive status

${ }^{16}$ Above n.5, para 47

${ }^{17}$ Above $\mathrm{n} .5$ para 50

${ }^{18}$ Above n.5, para 52

${ }^{19}$ Above n. 5 para 39

${ }^{20}$ Above n.5, para 59. A. Pedain, 'HIV and Responsible Sexual Behaviour', (2005) 64 Cambridge Law Journal, 540 , suggests another possible interpretation of this finding, one he describes as the 'informed consent' reading under which a person who remains ignorant of their partner's HIV status can never be said to consent to the risk of transmission.

${ }^{21}$ See Weait, 'Knowledge, Autonomy and Consent: R v Konzani' [2005] Criminal Law Review 763, at 765.

${ }^{22}$ Above $n .5$ para 47

${ }^{23}$ Above n.5, para 59

${ }^{24}$ See generally V. Munro, 'On responsible relationships and irresponsible sex - criminalising the reckless transmission of HIV R v Dica and Rv Konzani', (2007) 19 Child \& Fam. L. Q. 112

${ }^{25}$ Above n.5, para 59.

${ }^{26}$ M. Weait, 'Criminal law and the sexual Transmission of HIV: $R$ v Dica', (2005) 68(1) Modern Law Review 121 , at 127.

27 [2004] EWCA Crim 3246

${ }^{28}$ Ibid. para 10.

${ }^{29}$ Above n. 6 at para 39

30 See V. Munro, above n.24 at 117

${ }^{31}$ Above n. 6, at para 41

${ }^{32}$ Above n.6, at para 42

${ }^{33} \mathrm{Ibid}$. Cherkassky is broadly supportive of this finding arguing it is logical that the defendant cannot hold a reasonable belief in consent if he has not divulged his status. See L. Cherkassky, 'Being Informed: the complexities of knowledge, deception and consent when transmitting HIV', (2010) Journal of Criminal Law 242 at 248

${ }^{34}$ Above n.6 at para 42

35 Above n.6 at para 41

${ }^{36}$ See M. Weait, above n. 21 at 765 who suggests that this reasoning is based on faulty logic

${ }^{37}$ G. Mawhinney, 'To be ill or to kill: the criminality of contagion' (2013) Journal of Criminal Law 202, at 206. See also S. Matthiesson, 'Should the law Deal with Reckless HIV infection as a criminal offence or as a matter of public health?' (2010) 21 Kings Law Journal 123 at 129 who argues that the risk of transmission is an incidental consequence of sexual intercourse.

${ }^{38}$ See further M. Weait \& Y. Azad, 'The Criminalisation of HIV transmission in England and wales: Questions of Law and Policy', (2005) 10 HIV/AIDS Policy and Law Review, August 2005; M. Weait, above n.21 at 765

${ }^{39}$ See M. Weait, above n.21 at 766

${ }^{40}$ Above n.6. para 44

${ }^{41}$ See M. Weait, above n.21. The Crown Prosecution Guidelines take an equally narrow approach to what constitutes an informed consent. See Intentional or Reckless Sexual transmission of Infection: Legal Guidance available at

http://www.cps.gov.uk/legal/h to k/intentional or reckless sexual transmission of infection guidance/ accessed on July 172015 
${ }^{42}$ See further M. Weait, above n.21 at 766. Vanessa Munro, above n.24 at 117 argues that the court of appeal's conclusion in Konzani implied that 'the primary way in which such knowledge would be established would be through' the infected person.

${ }^{43}$ Above n.21 at 767.

${ }^{44}$ See L. Cherkassky, above n.33. Cherkassky further claims that by recognising that an informed consent can be given in the absence of disclosure by the defendant that Judge $L J$ created a loophole which allows a defendant to be 'completely reckless and places a significant burden on the victim to look into the sexual history of his or her partner before consenting' (at 254). Again I completely disagree, the 'loophole' created is extremely narrow.

${ }^{45}$ See M. Weait, above n.21 at 767

${ }^{46}$ See D. H. Ciccarone, D.E. Kanouse, R.L. Collins, A. Miu, J.L. Chen, S.C. Morton and R. Stall, 'Sex without Disclosure of Positive HIV Serostatus in a US Probability Sample of Persons receiving medical care for HIV Infection', (2003) 93 American Journal of Public Health, 949

${ }^{47}$ Above $\mathrm{n} .8$ at para 6.9. The issue of non-disclosure in the context of high risk sexual activity is not considered. For discussion of possible approaches to non-disclosure and a failure to use precaution see S. Ryan, 'Risktaking, Recklessness and HIV Transmission: Accommodating the reality of sexual transmission of HIV within a justifiable approach to criminal liability', (2007) 28 Liverpool Law Review, 215

${ }^{48}$ For an overview of cases see M. Weait, above n.9

${ }^{49}$ Above n.5 at para 11

${ }^{50}$ Above n. 40

${ }^{51} \mathrm{lbid}$. The guidance notes indicate that medical opinion on the reduction of risk is not settled and further that there may be evidential difficulties with this type of information whereas the use or non-use of a condom is more clear-cut.

${ }^{52}$ See L. Gostin \& J. Hodge, 'Piercing the Veil of Secrecy in HIV/AIDS and other sexually transmitted Diseases: Theories of Privacy and Disclosure in Partner Notification (1998) 5:9 Duke Journal of Gender Law \& Policy 9.

53 See Scoping Paper, above n. 8 at para 6.93.

${ }^{54} \mathrm{Ibid}$. where the argument that a general duty to disclose compromises the sexual freedom of HIV positive people is recognised. See also R. Bennett, H. Draper \& L. Frith, 'Ignorance is Bliss? HIV and moral duties and legal duties to forewarn'. (2002) 26 Journal of Medical Ethics, 9, and V. Tadros, 'Recklessness, Consent and the Transmission of HIV', [2000] Edinburgh Law Review, 371, at 377 who writes 'Given the value of sexual privacy, it is important that the law is restricted to an appropriate degree and in the appropriate way'.

${ }^{55}$ See V. Derlega, B. Winstead \& L. Folk-Barron, 'Reasons for and Against Disclosing HIV-Seropositive Test Results to an Intimate Partner: A Functional Perspective' in S. Petronio (ed), Balancing the Secrets of Private Disclosures, (Psychology Press, New York, 2014), 53

${ }^{56}$ See Gostin \& Hodges, above n. 52 at 66

${ }^{57}$ Gostin \& Hodges above n.52 at $62-67$

58 See Cherkassky, above n. 33

${ }^{59}$ See Gostin and Hodge, above n. 52 at 67. See further J. Flaherty, 'Clarifying the Duty to Warn in HIV Transference Cases', (2008) 54 Criminal Law Quarterly, 60 at 67 who argues 'the sexual partner becomes an unaware participant in a form of HIV transference Russian roulette

60 See Bennett et al, above n. 54 at 11; and M. Weait above n.26 at 127

${ }^{61}$ See M. Weait above n.26 at 128. See further M. Weait 'Taking the Blame: criminal law, social responsibility and the sexual transmission of HIV', (2001) 23:4 Journal of Social Welfare and family Law 441

62 See D. Ainslie, 'AIDS and Sex: Is Warning a Moral Obligation?' (2002) 10:1 Heath Care Analysis (2002) 49, M. Weait above n. 21

63 See M. Weait, above n.61 at 449.

${ }^{64} \mathrm{M}$. Cornett, 'Criminalisation of the Intended transmission or Knowing Non-Disclosure of HIV in Canada' (2011) 5:1 McGill Journal of Law and Health 61, at 66

${ }^{65}$ See Weait, above n. 61 at 451 who writes 'In those cases where HIV is purposively deployed as a weapon, the active/passive model in which $X$ is (and ought as a matter of judgment) to be held responsible for causing an effect in $Y$, rings true...But when the virus is transmitted in the course of sexual intimacy (understood as sexual conduct in which neither party is concerned purposively to harm the other), the distinction collapses. Transmission occurs between people engaged in such intimacy'.

66 M. Weait, above n.61 at 451

${ }^{67}$ Above n. 33 at 203/204 
${ }^{68}$ See Cornett above n. 64 at 70 although Cornett questions whether the criminal law is the appropriate mechanism for dealing with this complex issue. See further J. Flaherty, above n. 59

${ }^{69}$ Above n. 33 at 203

70 Above n.63 at 66

${ }^{71}$ Above n41. The Guidelines further state that when a safeguard ceases to be effective it is for the infected individual to disclose his or her status to their partner.

72 See 'The Boundaries of the Criminal law: The Criminalization of the Non-Disclosure of HIV' (2008) 31 Dalhousie Law Journal 123 at 172. Grant further agues 'if an accused finds it too difficult to disclose his or her HIV status, he or she should simply avoid unprotected sexual intercourse'.

${ }^{73}$ Ciccarone et al, above n.46 at 953. See also D. Warbuton, 'A Critical review of English law in respect of Criminalising Blameworthy Behaviour by HIV+ Individuals', (2004) 68 Journal of Criminal Law, 55, p. 65 and M.D. Stein, K.A. Freedberg, L.M. Sullivan, J. Savetsky, S.M. Levenson, R,Hingson and J.H. Samet, 'Sexual Ethics: Disclosure of HIV-Positive Status to Partners', (1998) 158 (3) Archives of Internal Medicine, 253

${ }^{74}$ M.A. Field \& K.M. Sullivan, 'AIDS and the Criminal Law' (1987) 15 Law, Medicine and Healthcare, 46, p.53.

${ }^{75}$ Above n.58 at 66

${ }^{76}$ See S. Ryan, above n.47,, Stein et al, above n.73 and J.A. Petrak, A.M. Doyle, A. Smith, C, Skinner and B. Hedge, 'Factors Associated with Self-Disclosure of HIV Serostatus to Significant Others' (2001) 6 British Journal of Health and Psychology 69

77 See for example Mawhinney, above n.37, at 203/204 who refers to the 'reckless sexual exploits of someone carrying a lethal communicable condition' and argues that 'the right not to be harmed must take precedence over social awkwardness every time in any morally sound person's mind'.

${ }^{78}$ See Ciccarone et al, above $\mathrm{n} .73$ and Stein et al above n.73

${ }^{79}$ See generally R. Elliot, After Cuerrier: Canadian Criminal law and the Non-Disclosure of HIV-positive status, Canadian HIV/AIDS Legal Network, 1999, p.24. See also S.C. Kalichman \& D. Nachimson, 'Self-efficacy and disclosure of HIV-positive serostatus to sex partners' (1999) 18 Health Psychology, 281 who found that HIVpositive women have greater difficulty disclosing to their HIV status to sexual partners than men. R. L. Sowell, B.F. Seals, K.D. Phillips \& C.H. Julius, 'Disclosure of HIV infection: how do women decide to tell', (2003) 1891) Health Education Research Theory \& Practice, 32, p.33 found that disclosure often triggered violence and that women in their study did not disclose because they felt it was too risky

${ }^{80}$ See J. Chalmers, 'The Criminalisation of HIC transmission', (2008) 28 Journal of Medical Ethics', 160 and M. Cornett, above n.64.

${ }^{81}$ See K.J. M Smith, 'Sexual Etiquette, Public Interest and the Criminal Law', (1991) 42 Northern Ireland Legal Quarterly, 309, at 328. M. Cornett, above n.64 at 98 writes 'on balance this is a situation which despite any moral reservations should accommodate policy considerations and recognise the low risk classification of protected sexual intercourse as a bar to criminal liability'. Bennett, Draper and Frith, above n.54 at 12 suggest 'when the risk is low it is possible to act in a responsible and morally justifiable way without forewarning'.

82 See M.A. Schlitz \& Th. G.M. Sandfort, 'HIV-positive people, risk and sexual behaviour' (2000) 50 Social Science \& Medicine 1571 at 1579

${ }^{83}$ See I. Grant, 'The Over-Criminalization of Person with HIV', (2013) 63 University of Toronto Law Journal 475, p.484 and Cornett, above n.64

${ }^{84}$ See L. Gostin, 'The Politics of AIDS' (1989) 49 Ohio Law Journal, 1017; G. Gillett, 'AIDS: The Individual and Society' in Legal Implications of AIDS Auckland: Legal Research Foundation, (1989); W.H. Holland, 'HIV/AIDS and the Criminal Law, (1994) 36(3) Criminal Law Quarterly, 279 and D. Ainslie above n. 62

${ }^{85}$ See I. Grant, above n.72 and M. Weait, above n. 21

${ }^{86}$ See S. Cowan, 'Offenses of sex or violence? Consent, fraud and HIV Transmission' (2014) 17(1) New Criminal Law Review, 135 at 149.

${ }^{87}$ Scoping Paper, above n.8 at para 6.92

${ }^{88}$ Above n.58, at 60

${ }^{89}$ Above n. 63, at 98

${ }^{90}$ There is much support for this approach to criminalisation in the academic commentary - see C. Strickland, 'Why Parliament should create HIV specific legislation' [2001] Web Journal of Current Legal Issues, R. Elliot, above n.9, and J.R. Spencer, 'Liability for reckless infection: Part 1' (2004) New Law Journal 384

${ }^{91}$ Of course it should be noted that there are many differences with the Canadian approach. HIV transmission often punished as an aggravated sexual offence, punishes exposure as well as transmission and on whole can be seen as taking a much broader approach to criminalisation than the UK. See further Grant above n.72 92 [1998] 2 SCR 371 
$93 \mathrm{lbid}$, at para 128

$94 \mathrm{Ibid}$, at para 129.

95 Ibid. Justice McLachlin (as she then was) stated in her minority opinion that protected sex would not be included as it did not pose a high risk of transmission.

${ }^{96}$ See generally I. Grant, 'The Prosecution of Non-disclosure of HIV in Canada: Time to Rethink Cuerrier (2011)

5 McGill Journal of Law and Health 7

${ }^{97}$ See $R v$ Agnatuk-Mercier [2001] OJ No 4729 (QL) and $R v$ Edwards 2001 NSS 80; $R v$ DC 2008 QCCQ 629, JE 2005-515 [DC (CQ)]

98 See $R$ v JT 2008 BCCA 463; $R$ v Wright 2009 BCCA 514

${ }^{99}$ See $R$ v Mekonnen 2009 ONCJ 643; R c Parenteau 2010 ONSC 1500

1002001 NSSC 80

1014 April 2009 CR-08-1735

1022008 QCCQ 629

1032010 QCCA 2289 [DC(CA)]. A different decision was reached by the Supreme Court see [2012] SCC 47

${ }^{104}$ Grant, above n. 96, at 30

105 Ibid. See further A. Symington, 'Injustice Amplified by HIV non-disclosure ruling' (2013) 63 University of

Toronto Law Review 485

106 [2012] SCC 47, [2012] SCC 48

107 [2012] SCC 47, para 84

108 lbid, at para 99

$109 \mathrm{lbid}$, at para 94

110 Ibid, at para 87.

${ }^{111}$ Grant, above $\mathrm{n} 83$ at 482

112 See I. Grant, above note 96 at 13

${ }^{113}$ See D. Hughes, 'Condon use, viral load and the type of sexual activity as defences to the sexual transmission of HIV' (2013) Journal of Criminal Law 136 and A. Symington, above n.105

${ }^{114}$ See A. Symington, above $\mathrm{n} .105$ at 489. It is worth bearing in mind that studies have found a transmission risk of $0.08 \%$ per act for unprotected vaginal sex- so a 89 to $96 \%$ reduction in that level of risk has to be considered a negligible risk.

${ }^{115}$ See A. Symington, above n.105 at 490

${ }^{116}$ See A. Symington, above n.105 at 488 . See also I. Grant, above n.111 at 482

117 See M. Shaffer, 'Sex, Lies and HIV: Marbior and the Concept of Sexual Fraud', (2013) 63 University of Toronto Law Journal 466 at 473

${ }^{118}$ See UNAIDS Criminalisation of HIV Non-Disclosure, Exposure and Transmission (2012)

${ }^{119}$ See generally the BASHH (British Association for Sexual health and HIV) guidelines on risk discussed by M. Fisher et al, 'UK Guideline for the use of post-exposure prophylaxis for HIV following sexual exposure', (2006) 17 Journal of STD \& AIDS, 81; R. Elliot, After Cuerrier: Canadian Criminal law and the Non-Disclosure of HIVpositive status, (Canadian HIV?AIDS Legal Network, 1999)

${ }^{120}$ See D. Hughes, above n.113. See further M. Shaffer, above n.117 at 471 who notes that 'a person with a low viral load has less than a 1, in 10,000 chance of infecting his or her partner through unprotected intercourse'. This is an issue that requires careful consideration however. How recently would a person's viral load have to have been tested? Moreover not everyone has regular access to testing and medication. See further I. Grant, above note 96 and A. Symington, above n. 105

${ }^{121}$ See I Grant, above n.96

122 See M. Boily et al, 'Heterosexual Risk of HIV-1 Infection per Sexual Act: Systematic review and MetaAnalysis of Observational Studies', (2009) 9:2 The Lancet Infectious Diseases 118. See further S. Ryan, above n.76 at 232

${ }^{123}$ See E Vittinghoff et al, 'Per-Contact Risk of Human Immunodeficiency Virus Transmission Between Male Sexual Partners', (1999) 150:3 American Journal of Epidemiology, 306. The Canadian case of $R v$ JT provides an interesting case study of this issue. - see further I. Grant, above n.96

124 [2008] BCCA 463 and [2010] BCSC 766

${ }^{125}$ At various stages there was disagreement as to how many acts of unprotected anal intercourse occurred with figures ranging from 2 to 6 . During the retrial it was accepted by Madam Justice Fenlon that 3 acts of unprotected anal intercourse had been established - see 2010 BCSC 766, at para 53

${ }^{126} 2008$ BCCA 463

127 Ibid, para 21 


\footnotetext{
${ }^{128} 2010$ BCSC 766, para 56

${ }^{129}$ Ibid, para $88 / 89$

${ }^{130}$ It is also essential that Crown Prosecution Guidelines are clear regarding what counts as a significant risk so that low risk cases are not brought to Court.

${ }^{131}$ See further Ryan, above n. 76, at $240-244$

132 See further R. Elliot, Criminal Law \& HIV/AIDS: Final Report (Canadian HIV/AIDS Legal Network and Canadian AIDS society, Montreal, 1996 who argues that a reasonable apprehension of physical violence upon disclosure or upon attempting to use precautions should constitute a defence to a charge of HIV transmission. 133 Grant, above n.96 at 10

${ }^{134}$ See $R$ v Stephenson [1979] QB 695 and JR Spencer, 'Liability for Reckless Infection: Part 1', (2004) New Law Journal, 384, p 385. See G. Mawhinney, above $\mathrm{n} .37$ at 211 recognises that this approach may be criticised on rule of law grounds.

135 (2005) 2 Cr App R 14 para 41 - my emphasis. Weait, above $\mathrm{n} .21$ at 766 described this interpretation as somewhat radical. See also M. Weait \& Y. Azad, above n.38.

136 [2014] EWCA Crim 889, para 66

137 [2014] EWCA Crim 889, para 83

${ }^{138}$ See A. Ashworth \& J. Horder, Principles of Criminal Law, $7^{\text {th }}$ edition, (Oxford University Press, 2013), page 177. See further A. Norrie, Crime, Reason and History, (London: Weidenfeld and Nicolson, 1993) at 80/81 where it is suggested that the question of justifiability of risk has been marginalised and filtered out. For an analysis of justifiability of risk-taking in the specific context of HIV transmission see S. Ryan, above n.76.

${ }^{139}$ Law Commission, Scoping Paper, para 2.96; 2.97; 3.33, 6.23. The Law commission recognises that there is some uncertainty as to whether this is an additional requirement but are in favour of having such a requirement recognised.

140 See A. Symington, above n.105

${ }^{141}$ For a more detailed consideration of how this can be achieved see S. Ryan, above n.76.
} 